\title{
The Global SEDIBUD (Sediment Budgets in Cold Environments) Programme: Coordinated Studies of Sedimentary Fluxes and Budgets in Changing Cold Climate Environments
}

\author{
Achim A. Beylich ${ }^{*}, 1,2$ \\ ${ }^{1}$ Geological Survey of Norway (NGU), Quaternary Geology \& Climate group, Trondheim, Norway \\ ${ }^{2}$ Norwegian University of Science and Technology (NTNU), Department of Geography, Trondheim, Norway
}

\begin{abstract}
Projected climate change in cold climate environments is expected to alter melt-season duration and intensity, along with the number of extreme rainfall events, total annual precipitation and the balance between snowfall and rainfall. In addition, changes to the thermal balance are expected to reduce the extent of permafrost and seasonal ground frost and increase active layer depth. These effects will change surface environments in cold climate environments and alter the fluxes of sediments, nutrients and solutes, but the absence of data and coordinated quantitative analysis to understand the sensitivity of the surface environment are acute in cold environments. The I.A.G/A.I.G. SEDIBUD (Sediment Budgets in Cold Environments) Programme, building on the ESF SEDIFLUX (Sedimentary Source-to-Sink-Fluxes in Cold Environments) Network, has been formed to address this key knowledge gap. Coordinated efforts are carried out to quantify, compare and model sedimentary fluxes and budgets in 38 selected SEDIBUD Key Test Sites (cold environment catchments) worldwide.
\end{abstract}

Keywords: Sediment fluxes, sediment budgets, geomorphic process monitoring, inter-site comparisons, cold climate environments.

\section{INTRODUCTION}

Amplified climate change and ecological sensitivity of polar and cold environments have been highlighted as a key global environmental issue [1]. Projected climate change in cold regions is expected to alter melt season duration and intensity, along with the number of extreme rainfall events, total annual precipitation and the balance between snowfall and rainfall. Similarly, changes to the thermal balance are expected to reduce the extent of permafrost and seasonal ground frost and increase active layer and thaw depths. These effects will undoubtedly change surface environments in cold environments and alter the fluxes of sediments, nutrients and solutes, but the absence of data and analysis to understand the sensitivity of the surface environment are acute in cold climate environments.

\section{THE I.A.G./A.I.G. SEDIBUD PROGRAMME}

The SEDIBUD (Sediment Budgets in Cold Environments) Programme of the International Association of Geomorphologists (I.A.G./A.I.G.) was formed in 2005 to address this key knowledge gap $[2,3]$.

SEDIBUD has currently about 400 members worldwide and the Steering Committee of this international programme is composed of ten scientists from nine different countries:

Achim A. Beylich (Chair) (Norway), Armelle Decaulne (Secretary) (France), John C. Dixon (USA), Scott F.

*Address correspondence to this author at the Geological Survey of Norway (NGU), Quaternary Geology \& Climate group, Trondheim, Norway;

Tel: ++47 7390 4117; E-mail: achim.beylich@NGU.NO
Lamoureux (Vice-Chair) (Canada), John F. Orwin (New Zealand), Jan-Christoph Otto (Austria), Irina Overeem (USA), Porsteinn Sæmundsson (Iceland), Jeff Warburton (UK), and Zbigniew Zwolinski (Poland).

The central research question of this global group of scientists is to;

Assess the contemporary sedimentary fluxes in cold climates, with emphasis on both particulate and dissolved components.

Initially formed in 2004 as the European Science Foundation (ESF) Network SEDIFLUX (Sedimentary Source-to-Sink-Fluxes in Cold Environments) (2004-2006) $[4,5]$ SEDIBUD has further expanded to a global group of researchers with field research sites located in polar and alpine regions in the northern and southern hemisphere. Research carried out at each site varies by programme, logistics and available resources, but typically represent interdisciplinary collaborations of geomorphologists, hydrologists, ecologists, and permafrost scientists and glaciologists with different levels of detail. SEDIBUD has developed a key set of primary research data requirements intended to incorporate results from these varied projects and allow analysis across the programme. SEDIBUD Key Test Sites provide data on annual climate conditions, total discharge and particulate and dissolved fluxes as well as information on other relevant denudative surface processes. A number of selected SEDIBUD Key Test Sites is providing high-resolution (hourly) data on climatic conditions, runoff and fluvial fluxes, which in addition to the annual data contribute to the SEDIBUD Metadata Database. To support these efforts, the SEDIFLUX Manual and field protocols [6] 
Table 1. Compiled Annual Data from SEDIBUD Key Test Sites

Required Annual Data from SEDIBUD Key Test Sites (Protocol Available at http://www.geomorph.org/wg/wgsb.html [9])

\begin{tabular}{|l|l|}
\hline $\begin{array}{l}\text { Name of SEDIBUD Key Test Site: } \\
\text { Erdalen (Norway) } \\
\text { Principal Investigator: Achim A. Beylich }\end{array}$ & $\begin{array}{l}\text { Period of Investigations (Years): 2005 - 2009 } \\
\text { Publishedogical Year (HY) or Calender Year (CY); }\end{array}$ \\
\hline \hline Mean annual temperature $\left({ }^{\circ} \mathrm{C}\right)$ & 6.1 \\
\hline Total annual precipitation $[\mathrm{mm}]$ & 1452 \\
\hline Total annual runoff $[\mathrm{mm}]$ & 1413 \\
\hline Annual suspended sediment yield $\left[\mathrm{t} \mathrm{km}^{-2}\right]$ & 7.8 \\
\hline Annual solute yield (atmospherically corrected) $\left[\mathrm{t} \mathrm{km}^{-2}\right]$ & 3.3 \\
\hline
\end{tabular}

\section{Required Annual Data from SEDIBUD Key Test Sites}

\begin{tabular}{|l|l|}
\hline $\begin{array}{l}\text { Name of SEDIBUD Key Test Site: } \\
\text { Hrafndalur (Iceland) } \\
\text { Principal Investigator: Achim A. Beylich }\end{array}$ & $\begin{array}{l}\text { Period of Investigations (Years): 2002 - 2007 } \\
\text { (Hydrological Year (HY) or Calender Year (CY); } \\
\text { Published Data (PD) or Unpublished Data (UPD)) }\end{array}$ \\
\hline \hline Mean annual temperature $\left({ }^{\circ} \mathrm{C}\right)$ & 3.6 \\
\hline Total annual precipitation $[\mathrm{mm}]$ & 1719 \\
\hline Total annual runoff $[\mathrm{mm}]$ & 1344 \\
\hline Annual suspended sediment yield $\left[\mathrm{t} \mathrm{km}^{-2}\right]$ & 18.5 \\
\hline Annual solute yield (atmospherically corrected) $\left[\mathrm{t} \mathrm{km}^{-2}\right]$ & 29.3 \\
\hline
\end{tabular}

\section{Required Annual Data from SEDIBUD Key Test Sites}

\begin{tabular}{|l|l|}
\hline $\begin{array}{l}\text { Name of SEDIBUD Key Test Site: } \\
\text { Austdalur (Iceland) } \\
\text { Principal Investigator: Achim A. Beylich }\end{array}$ & $\begin{array}{l}\text { Period of Investigations (Years): 1996-2007 } \\
\text { (Hydrological Year (HY) or Calender Year (CY); } \\
\text { Published Data (PD) or Unpublished Data (UPD)) }\end{array}$ \\
\hline \hline Mean annual temperature $\left({ }^{\circ} \mathrm{C}\right)$ & 3.6 \\
\hline Total annual precipitation $[\mathrm{mm}]$ & 1431 \\
\hline Total annual runoff $[\mathrm{mm}]$ & 1130 \\
\hline Annual suspended sediment yield $\left[\mathrm{t} \mathrm{km}^{-2}\right]$ & 42.0 \\
\hline Annual solute yield (atmospherically corrected) $\left[\mathrm{t} \mathrm{km}^{-2}\right]$ & 8.0 \\
\hline
\end{tabular}

\section{Required Annual Data from SEDIBUD Key Test Sites}

Name of SEDIBUD Key Test Site:

Latnjavagge (Sweden)

Principal Investigator: Achim A. Beylich

\begin{tabular}{|l|l}
\hline \hline Mean annual temperature $\left({ }^{\circ} \mathrm{C}\right)$ & \\
\hline Total annual precipitation $[\mathrm{mm}]$ & \\
\hline Total annual runoff $[\mathrm{mm}]$ & \\
\hline Annual suspended sediment yield $\left[\mathrm{t} \mathrm{km}^{-2}\right]$ & 2. \\
\hline Annual solute yield (atmospherically corrected) $\left[\mathrm{t} \mathrm{km}^{-2}\right]$ & 4. \\
\hline
\end{tabular}

Period of Investigations (Years): 2000 - 2007

(Hydrological Year (HY) or Calender Year (CY);

Published Data (PD) or Unpublished Data (UPD))

\begin{tabular}{|l|}
\hline-2.0 \\
\hline 852 \\
\hline 717 \\
\hline 2.3 \\
\hline 4.6 \\
\hline
\end{tabular}

\section{Required Annual Data from SEDIBUD Key Test Sites}

\begin{tabular}{|l|l|}
\hline $\begin{array}{l}\text { Name of SEDIBUD Key Test Site: } \\
\text { Kidisjoki (Finland) } \\
\text { Principal Investigator: Achim A. Beylich }\end{array}$ & $\begin{array}{l}\text { Period of Investigations (Years): 2002-2007 } \\
\text { (Hydrological Year (HY) or Calender Year (CY); } \\
\text { Published Data (PD) or Unpublished Data (UPD)) }\end{array}$ \\
\hline \hline Mean annual temperature $\left({ }^{\circ} \mathrm{C}\right)$ & -2.0 \\
\hline Total annual precipitation $[\mathrm{mm}]$ & 415 \\
\hline Total annual runoff $[\mathrm{mm}]$ & 324 \\
\hline Annual suspended sediment yield $\left[\mathrm{t} \mathrm{km}^{-2}\right]$ & 0.3 \\
\hline Annual solute yield (atmospherically corrected) $\left[\mathrm{t} \mathrm{km}^{-2}\right]$ & 3.1 \\
\hline
\end{tabular}

The five examples Erdalen (Norway) [10], Hrafndalur (Iceland) [11, 12], Austdalur (Iceland) [12], Latnjavagge (Sweden) [13, 11] and Kidisjoki (Finland) [11]. Time series of these mean annual data are published in [10,11 and 12] and [13]. 
have been produced to establish common methods and data standards [2, 3] in press [7]. In addition, a framework paper for characterizing fluvial sediment fluxes from source to sink in cold environments has been published by the group [8]. Comparable datasets from different SEDIBUD key test sites will be analysed to address key research questions of the SEDIBUD programme as defined in the SEDIBUD Working Group Objective [9]. Table 1 shows compiled annual data, as required from defined SEDIBUD Key Test Sites, from five selected SEDIBUD research field sites as examples. The generation and compilation of directly comparable data sets from the defined SEDIBUD Key Test Sites in the SEDIBUD Metadata Database will be the basis for modelling effects of climate change on sedimentary fluxes and yields in cold climate environments by using space-for-time substitution [2-6]. Currently SEDIBUD has identified 38 SEDIBUD Key Test Sites worldwide [9] with the goal to further extend this network to about 40-45 sites that possibly cover the widest range of cold environments.

Additionally, it is expected that collaboration within the group will act as a catalyst to develop new sites in underrepresented regions. The SEDIBUD Key Test Site Database [14] and the SEDIBUD Fact Sheets Volume [15] provide significant information on SEDIBUD Key Test Sites. SEDIBUD is open for proposals for possible additional SEDIBUD Key Test Sites to be included in the programme.

Coordination and collaboration with a number of international research programmes, including: International Tundra Experiment (ITEX), Circumpolar Active Layer Monitoring (CALM) and Arctic Coastal Dynamics (ACD/ACCO Net) will provide further opportunities for collaborative research to address broader polar environmental research issues [16-18].

Individual research projects being headed by SEDIBUD Members, using datasets generated at SEDIBUD Key Test Sites and targeting at defined SEDIBUD Key Research Questions, using SEDIBUD as umbrella programme, are encouraged by the SEDIBUD Steering Committee. More detailed information on the I.A.G./A.I.G. SEDIBUD Programme is available at http://www.geomorph.org/wg/wgs b.html [9].

\section{ACKNOWLEDGEMENTS}

The author thanks the SEDIBUD Steering Committee Members and numerous SEDIBUD Members for fruitful discussions and numerous valuable inputs.

\section{REFERENCES}

[1] ACIA, Impacts of a Warming Arctic: Arctic Climate Impact Assessment. ACIA Overview Report. Arctic Climate Impact Assessment: Cambridge University Press 2004

[2] A.A. Beylich, "Quantitative studies on sediment fluxes and sediment budgets in changing cold environments - potential and expected benefit of coordinated data exchange and the unification of methods", Landform Analysis, vol. 5, pp. 9-10, 2007.

[3] A.A. Beylich, S.F. Lamoureux, and A. Decaulne, "Coordinated quantitative studies on sediment fluxes and sediment budgets in changing cold environments - examples from three SEDIBUD key test sites in Canada, Iceland and Norway", Landform Analysis, vol. 5, pp. 11-12, 2007.

[4] A.A. Beylich, S. Etienne, B. Etzelmüller, V.V. Gordeev, J. Käyhkö, V. Rachold, A.J. Russell, K.-H. Schmidt, Th. Sæmundsson, F.S. Tweed, and J. Warburton, "Sedimentary Sourceto-Sink-Fluxes in Cold Environments - Information on the European Science Foundation (ESF) Network SEDIFLUX", Zeitschrift für Geomorphologie N.F., Suppl.-Vol. 138, pp. 229-234, 2005.

[5] A.A. Beylich, S. Etienne, B. Etzelmüller, V.V. Gordeev, J. Käyhkö, V. Rachold, A.J. Russell, K.-H. Schmidt, Th. Sæmundsson, F.S. Tweed, and J. Warburton, "The European Science Foundation (ESF) Network SEDIFLUX - An introduction and overview", Geomorphology, vol. 80, no. 1-2, pp. 3-7, 2006.

[6] A.A. Beylich, and J. Warburton, Eds., Analysis of Source-to-SinkFluxes and Sediment Budgets in Changing High-Latitude and High-Altitude Cold Environments. SEDIFLUX Manual, $N G U$ Report, 2007.053, p. 158, 2007.

[7] A.A. Beylich, S.F. Lamoureux, and A. Decaulne, "Developing quantitative frameworks for studies on sedimentary fluxes and budgets in changing cold environments", Polish Polar Research, (in press).

[8] J.F. Orwin, S.F. Lamoureux, J. Warburton, and A.A. Beylich, “A framework for characterizing fluvial sediment fluxes from source to sink in cold environments", Geografiska Annaler, A, vol. 92, no. 2, pp. 155-176, 2010.

[9] SEDIBUD Website. Available from: http://www.geomorph.org/ wg/wgsb.html, 17.03.2010.

[10] A.A. Beylich, S. Liermann, and K. Laute, "Fluvial transport during thermally and pluvially induced peak runoff events in a glacier-fed mountain catchment in western Norway", Geografiska Annaler, A, vol. 92, no. 2, pp. 215-224, 2010.

[11] A.A. Beylich, "Chemical and mechanical fluvial denudation in cold environments - Comparison of denudation rates from three catchments in sub-Arctic Eastern Iceland, sub-Arctic Finnish Lapland and Arctic Swedish Lapland", Jökull, vol. 59, pp. 19-32, 2009

[12] A.A. Beylich, and Ch. Kneisel, "Sediment budget and relief development in Hrafndalur, sub-Arctic oceanic eastern Iceland", Arctic, Antarctic and Alpine Research, vol. 41, no. 1, pp. 3-17, 2009.

[13] A.A. Beylich, "Mass transfers, sediment budget and relief development in the Latnjavagge catchment, Arctic oceanic Swedish Lapland", Zeitschrift für Geomorphologie N.F., vol. 52, no. 1, pp. 149-197, 2008.

[14] K. Laute, D. Gintz, and A.A. Beylich, SEDIBUD Key Test Site Database. Available online at http://www.geomorph.org/wg/wgsb. html, 17.03.2010.

[15] S.F. Lamoureux, A. Decaulne, and A.A. Beylich, Eds., SEDIBUD Test Sites: Fact Sheets. $1^{\text {st }}$ Edition June 2008. Available from: http://www.lulu.com, ID: 3111308, 2008.

[16] S.F. Lamoureux, A.A. Beylich, and A. Decaulne, "Sediment Fluxes and Budgets in Changing High-Latitude and High-Altitude Cold Environments. Sediment Budgets in Cold Environments (SEDIBUD) Second Workshop; Abisko, Sweden, 15-19 September 2007", EOS, vol. 88, no. 52, p. 580, 2007.

[17] A.A. Beylich, S.F. Lamoureux, and A. Decaulne, "SEDIBUD Sediment budgets in cold environments: Introduction", Zeitschrift für Geomorphologie N.F., vol. 52, no. 1, pp. 1-2, 2008.

[18] A.A. Beylich, S.F. Lamoureux, and A. Decaulne, "Sediment Budgets in Cold Environments - The SEDIBUD Program: Introduction", Arctic, Antarctic, and Alpine Research, vol. 41, no. 1, pp. 1-2, 2009.

This is an open access article licensed under the terms of the Creative Commons Attribution Non-Commercial License (http://creativecommons.org/licenses/by-nc/ 3.0/) which permits unrestricted, non-commercial use, distribution and reproduction in any medium, provided the work is properly cited. 